Volodymyr Sysoiev, Doctor of Economics, Full Professor, National Technical University «Kharkiv polytechnic Institute», Department of Economics and Marketing, Kharkiv, ORCID ID 0000-0001-6125-7051, E-mail: sysoevvv@ukr.net

Viktoria Pysmak, PhD in Economic Science, Associate Professor, Simon Kuznets Kharkiv National University of Economics, Department of Management, Logistics and Economics, Kharkiv, ORCID ID 0000-0002-6148-1712,

E-mail: viktoria.pysmak@ukr.net

https://doi.org/10.29038/2411-4014-2020-01-117-128

\title{
DIAGNOSTICS OF ENTERPRISE LOGISTIC ACTIVITY
}

\begin{abstract}
The main theoretical and methodological provisions of diagnostics of enterprise logistic activity as a tool of management process are investigated, it provides timely response to problems in organization of the enterprise logistics system and creation of preconditions for increasing the efficiency of its logistic activity. The mechanism of diagnostics of enterprise logistic activity in the form of a complex system, which integrates indicators, methods, special measures and procedures of research of its results in the conditions of various influence factors is proposed, is based on the basic principles of economic diagnostics and aims at achieving the goals of diagnostics. The essence of the main components of the diagnostic mechanism of enterprise logistic activity is revealed, their variety, interdependence and peculiarities of application are shown, that provides complexity and consistency in the study of a wide range of issues of organization and operation of the enterprise logistics system, as well as in evaluating the effectiveness of logistic solutions.
\end{abstract}

Keywords: diagnostics, logistic activity, enterprise, diagnostic mechanism, influence factors, indicators, diagnostic methods.

Сысоев Владимир, доктор экономических наук, профессор, Национальный технический университет «Харьковский политехнический институт», кафедра экономики и маркетинга, г. Харьков,

Письмак Виктория, кандидат экономических наук, доцент, Харьковский национальной экономический университет имени Семена Кузнеца, кафедра менеджмента, логистики и экономики, г. Харьков,

\section{ДИАГНОСТИКА ЛОГИСТИЧЕСКОЙ ДЕЯТЕЛЬНОСТИ ПРЕДПРИЯТИЯ}

Аннотация. Исследованы основные теоретико-методологические положения диагностики логистической деятельности предприятия как инструмента процесса управления, обеспечивающего своевременное реагирование на возникновение проблем в организации системы логистики предприятия и создание предпосылок повышения эффективности его логистической деятельности. Предложен механизм диагностирования логистической деятельности предприятия в виде сложной системы, объединяющей показатели, методы, специальные мероприятия и процедуры исследования ее результатов в условиях воздействия различных факторов, основывающейся на базовых принципах экономической диагностики и направленной на достижение целей диагностики. Раскрыта сущность основных составляющих механизма диагностики логистической деятельности предприятия, показано их многообразие, взаимообусловленность и особенности применения, что обеспечивает комплексность и системность в исследовании широкого круга 
вопросов организации и функционирования системы логистики предприятия, а также в оценке эффективности логистических решений.

Ключевые слова: диагностика, логистическая деятельность, предприятие, механизм диагностики, факторы влияния, показатели, методы диагностики.

Сисоєв Володимир, доктор економічних наук, професор, Національний технічний університет «Харківський політехнічний інститут», кафедра економіки та маркетингу, м. Харків,

Письмак Вікторія, кандидат економічних наук, доцент, Харківський національний економічний університет імені Семена Кузнеця, кафедра менеджменту, логістики та економіки, м. Харків,

\section{ДІАГНОСТИКА ЛОГІСТИЧНОЇ ДІЯЛЬНОСТІ ПІДПРИЕМСТВА}

Анотація. Ключову роль у вирішенні проблеми забезпечення менеджменту підприємства інформацією про стан логістичної системи та результативність логістичних процесів, існуючі й потенційні проблеми в реалізації логістичних функцій, альтернативні підходи до їх вирішення відіграє діагностика, яка грунтується на комплексному та системному дослідженні усіх сторін логістичної діяльності підприємства.

Метою дослідження є розкриття основних теоретико-методологічних положень діагностики логістичної діяльності підприємства через формування механізму їі реалізації.

Результати. Досліджено основні теоретико-методологічні положення діагностики логістичної діяльності підприємства як інструменту процесу управління, що забезпечує своєчасне реагування на виникнення проблем в організації системи логістики підприємства і створення передумов підвищення ефективності його логістичної діяльності. Запропоновано механізм діагностування логістичної діяльності підприємства у вигляді складної системи, яка об'єднує показники, методи, спеціальні заходи і процедури дослідження ііі результатів в умовах впливу різних факторів, грунтується на базових принципах економічної діагностики і спрямована на досягнення цілей діагностики. Визначені об’єкти діагностування та особливості їх дослідження. Виділені загальні та часткові результати логістичної діяльності підприємства, які є основним предметом діагностики. Приведена класифікація факторного простору системи логістики підприємства, який впливає на результати його логістичної діяльності. Запропонована система показників, яка містить ключові та локальні показники з їх підпорядкованістю і диференціацією, що забезпечує комплексне оцінювання різних аспектів, видів та характеристик системи логістики підприємства. Окреслені основні групи методів діагностики логістичної діяльності, вибір яких залежить від iї конкретних напрямів в розрізі функціональних логістичних підсистем підприємства.

Висновки. Доказано, що запропонований механізм діагностики логістичної діяльності $є$ ефективним інструментом процесу управління виробничо-господарською діяльністю підприємства, який дозволяє досліджувати широке коло питань організації та функціонування системи логістики підприємства, а також оцінювати ефективність логістичних рішень.

Ключові слова: діагностика, логістична діяльність, підприємство, механізм діагностики, фактори впливу, показники, методи діагностики

Formulation of the problem. The enterprise logistic activity covers almost all types of production and economic activity, integrating and coordinating the work of various structural divisions of the enterprise in order to optimize its resources, increase the level of customer service and obtain competitive advantages through integrated, needs-oriented, rational management of material and related flows at the stages of purchase of raw materials, production and distribution of finished products.

Efficiency of management of the enterprise logistic activity in the conditions of variability of internal and external environment depends on providing management of the enterprise with information on a condition of its logistics system and efficiency of logistics processes, existing and potential problems in 
realization of logistic functions, alternative approaches to their solution. The key role in solving this problem is played by diagnostics, which is based on a comprehensive and systematic study of all aspects of the enterprise logistic activity. The purpose of diagnostics allows to form the information system of support of decision-making of logistic decisions and to define ways of influence on various parameters of logistics system and logistics processes of the enterprise. That is, diagnostics is an instrument of the management process that provides timely response to problems in the organization of the enterprise logistics system and creation of preconditions for improving the efficiency of its logistic activities.

Various areas of application, multivariate and multifaceted logistic activity of enterprises, dependence on many factors of influence and use of various indicators of its evaluation determine the importance of diagnostics of logistic activity of enterprises, which requires systematization and further development of its theoretical and methodological principles.

The analysis of researches and publications. The problem of diagnosing logistic activities lies in the complexity of the entire functional complex of enterprise logistics in the conditions of variability and uncertainty of their external and internal environments.

In scientific works devoted to diagnostics of business activity of the enterprise, the logistical aspects (system, processes) were considered quite generalized, without taking into account the peculiarities of their organization, functioning or realization [1 - 3]. The definition of the concept of "diagnostics of the enterprise logistic activity" was first proposed by Melnyk O. [4], which also outlined the possible components of an appropriate diagnostic system. The paper [5] deals with the use of different principles of diagnostics to obtain additional experimental data, which allow to improve the quality of diagnostics of the enterprise logistic activity. Posylkina O. and Khromykh A. developed methodological recommendations for diagnosing the potential of intra-logistic integration of processes in domestic pharmaceutical enterprises [6]. Some components of the problem are highlighted in logistic analysis and audit, which are diagnostic tools [7 - 9]. Most of the scientific researches within the given problem are connected with the choice of indicators of the enterprise logistic activity [10 - 13] and development of methodical approaches to their estimation [14 - 17]. Attempts to address the problem are comprehensively limited to certain functional areas of enterprise logistics: procurement [18, 19], production [20] or marketing [21].

The lack of a comprehensive vision of the problem of diagnosing logistic activity of enterprises and the lack of methodological bases for its conduct necessitate the systematization of the components of this process, which requires clarification of the essence and tasks of diagnostics, outlining the basic principles and methods of its implementation, determining indicators of evaluation of external logistics activities her.

The purpose of the work. The purpose of the study is to reveal the main theoretical and methodological provisions of diagnostics of the enterprise logistic activity through the formation of the mechanism of its implementation.

Presentation of the main research material. In a broad scientific sense, logistics is considered as the implementation of basic and supportive logistics functions through logistics processes and operations that are associated with changing the parameters of space (location), time, form and properties of logistics (material, information, financial, service) flows from optimal cost of resources. In a narrow practical sense, the enterprise logistic activity covers a complex of processes of supplying material resources, supporting production procedures, inventory formation, warehousing, transportation and sale of finished products.

Logistics management of the enterprise is aimed at optimizing the utilization of production capacity, reducing costs and inventories at all stages of the extended reproduction cycle, accelerating working capital turnover, ensuring the reliable fulfillment of contractual obligations for the supply of finished products and complete satisfaction of consumers in the quality of products and services. This type of management is associated with some difficulties, due to the peculiarities of organization and logistics in enterprises:

- the diversity, interconnection and interdependence of logistics processes in the enterprise;

- implementation of logistics processes by different functional units of the enterprise;

- combination of organizational, economic, technological, technical and legal aspects in logistic activity;

- significant dependence of the enterprise logistic activity on interaction with the external microenvironment (suppliers, intermediaries, consumers);

- lack of a clear system for collecting and analyzing information about the organization, efficiency and bottlenecks of the enterprise logistics system. 
Making effective management decisions in these circumstances requires the identification, analysis, evaluation and forecasting of logistics problems of the enterprise, most of which are poorly structured or mixed, containing qualitative and quantitative indicators of logistic activities.

Such complex research is carried out by continuous diagnostics of logistic activity, which is an integral part of the enterprise management system and provides measurement of characteristics of logistics processes, analysis of influence of internal and external factors on them, expert evaluation of the developed measures for overcoming crisis phenomena or achievement of the set goals of increasing logistical activity efficiency and development of the enterprise logistics system.

Effective diagnostics requires the development of an appropriate mechanism that allows to clearly regulate the order and progress of the study of logistics processes. The expediency of developing the mechanism of diagnostics of the enterprise logistic activity is determined by the need of:

- identification of weaknesses and strengths of the logistics system of the enterprise;

- identification and evaluation of threats and opportunities arising in the process of logistics;

- timely recognition of logistical problems and adequate response to them;

- monitoring of related areas of activity of the enterprise that influence the functioning of the logistics system;

- setting priorities when choosing alternative options and making informed logistical decisions;

- providing flexibility and adaptability of the logistics system of the enterprise to changes of its external and internal environments.

The main result of the diagnostics of logistic activities is the analytical reproduction in the economic indicators of quantitative and qualitative characteristics of logistics processes at the enterprise. Due to the fact that the efficiency of logistics activities depends on the validity of making certain managerial decisions, the diagnostic system makes it possible to predict the signs of positive or destructive processes in the production and economic activity of the enterprise.

The mechanism of diagnostics of the enterprise logistic activity is a complex system category, which is a system of interrelated and interdependent indicators, methods, special measures and procedures of research of results of logistic activity in the conditions of influence of factors of external and internal environment of the enterprise, based on the main principles of economic diagnostics and directed to achieve the goals of diagnostics (Fig. 1).

The purpose of logistic activity diagnostics is a systematic study of logistics processes implemented by the logistics system in the course of production and economic activity of the enterprise, interpretation of the results of their evaluation and development of a set of measures aimed at improving their efficiency.

The objects of diagnostics of the enterprise logistic activity are the logistics system, its functional subsystems and units that implement logistics processes and operations related to the management of material, information, financial and service flows that are formed during the production and economic activity of the enterprise.

The subject of diagnostics of the enterprise logistic activity are the results of this activity, obtained under the influence of various factors of external and internal environment.

The purpose of diagnostics of the enterprise logistic activity is achieved by solving a complex of tasks, the main among which are:

- positioning the logistics system in the overall structure of the enterprise and identifying the impact of logistics on its performance;

- identification of sources of excess and hidden logistical losses;

- identification of resource intensity of existing logistics processes and identification of potential areas for their improvement;

- analysis of the effectiveness of interaction between subsystems and units of the logistics system of the enterprise and relations with the members of the logistics chains, which it includes;

- evaluation of logistical risks and rationality of managerial decisions to eliminate the factors that destabilize the enterprise logistic activity;

- forecasting changes in the logistic activity of the company, caused by management decisions. 


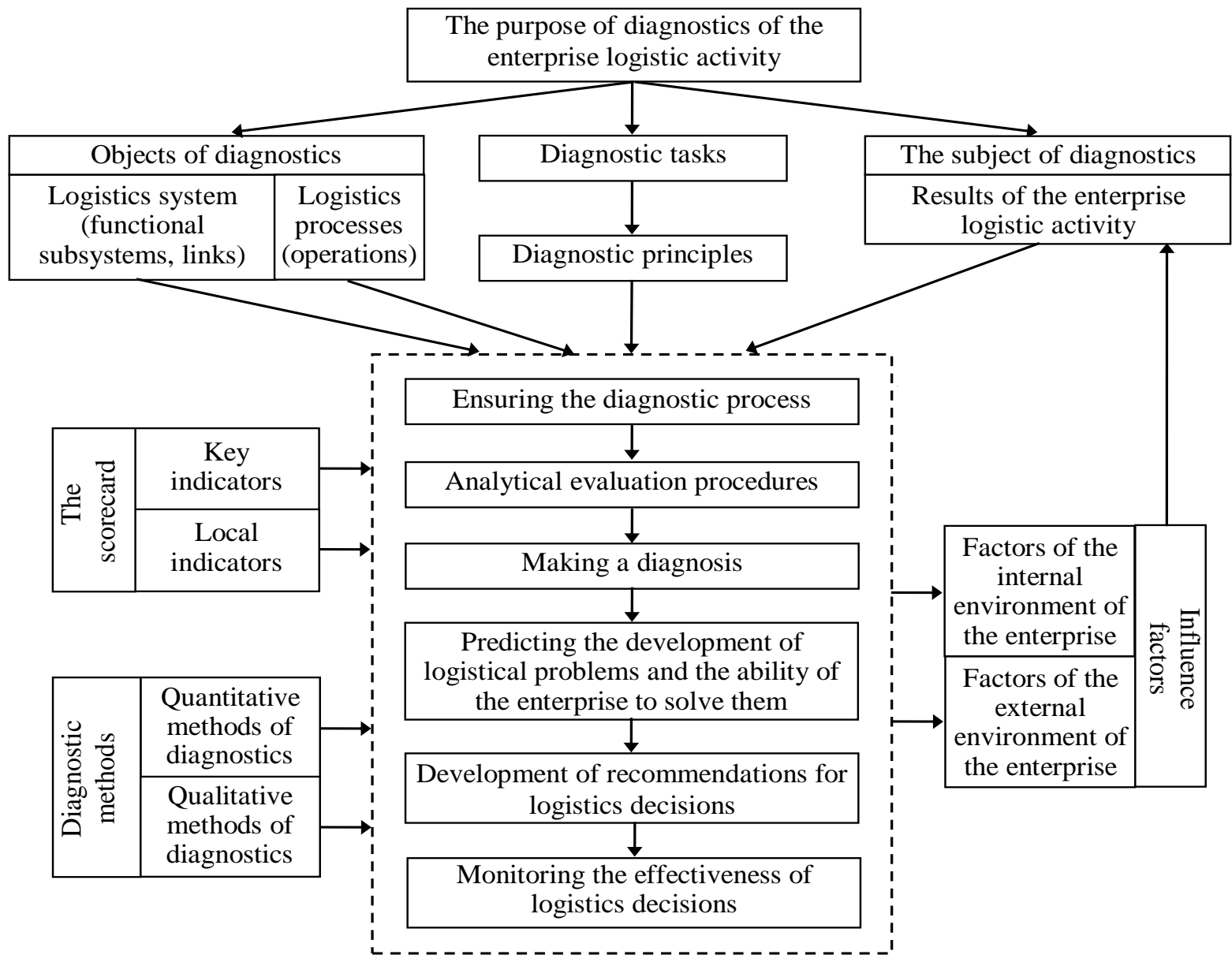

Fig. 1. The mechanism of diagnostics of the enterprise logistic activity

Source: developed by the authors.

Diagnostics of the enterprise logistic activity is based on basic principles of economic diagnostics, which are connected both with its estimation and with identification of potential possibilities for its improvement (Fig. 2).

The organization and implementation of logistics is provided by the logistics system of the enterprise, which integrates the unified management of material and related flows of its structural and functional units, as well as suppliers, intermediaries and consumers to optimize costs and streamline the processes of procurement, production and marketing.

The main goal of managing the logistics system of the enterprise is to achieve a high level of its system characteristics: viability, innovation, integration, reliability and adaptability (Table 1) by improving the application characteristics that reflect the quantitative parameters of the components of the logistics system, organization of its functioning and contribution.

The quantitative parameters of the components of the logistics system reflect the capacities and technical characteristics of the logistics assets of the enterprise, which include warehouses, transport, equipment (technological, lifting and transport, equipment for identification and determination of weight of goods), logistic information systems and stocks.

Characteristics of the organization of functioning of the logistics system describe its goals and objectives, logistics strategy, enterprise logistics management system and its organizational structure, characterize the logistics technologies used in the areas of supply, production and distribution, personnel potential of logistics units and their organizational culture. 


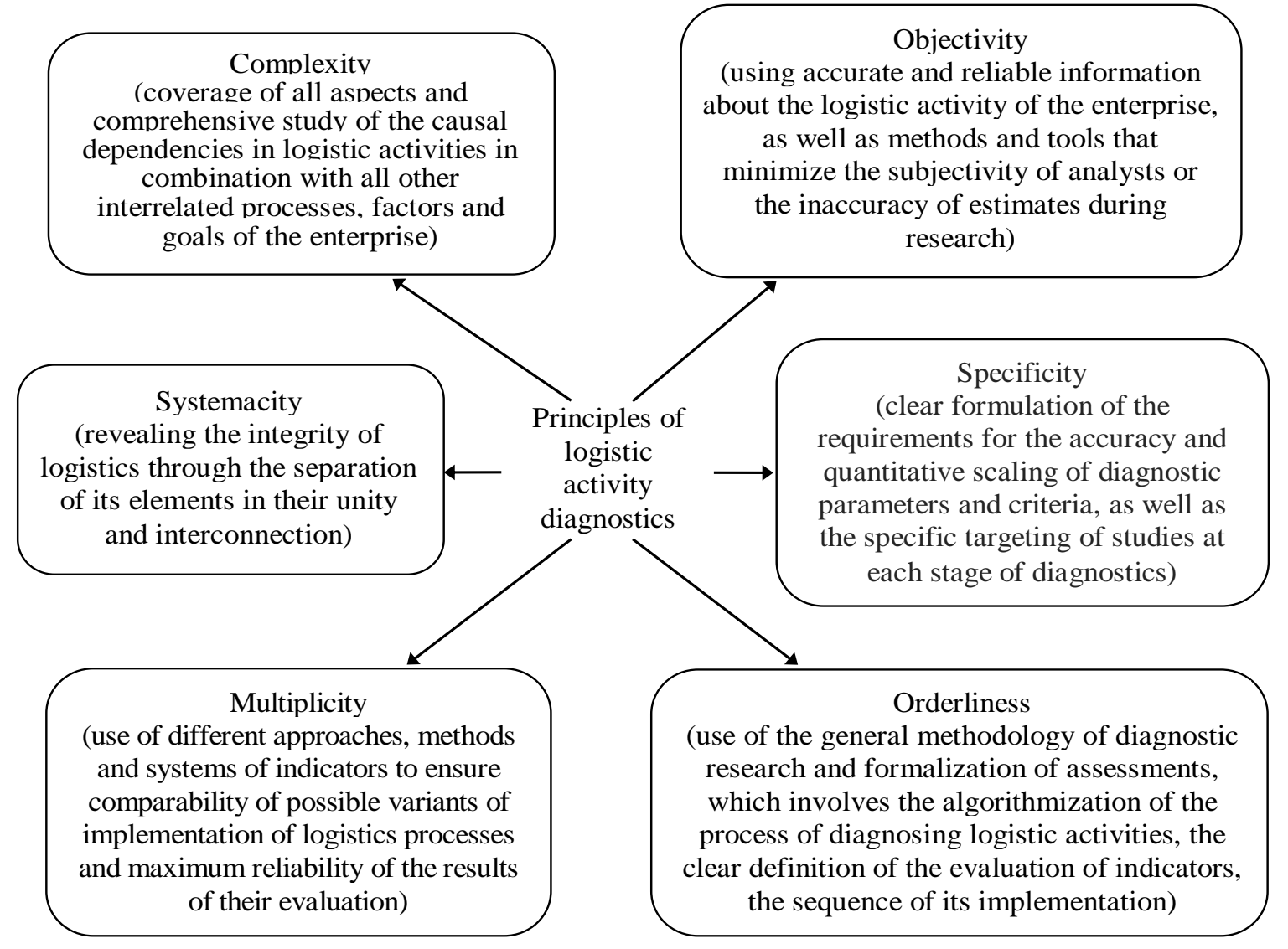

Fig. 2. Principles of diagnostics of the enterprise logistic activity Source: $[1-4]$.

System characteristics of the logistics system of the enterprise

\begin{tabular}{|l|l|}
\hline \multicolumn{1}{|c|}{ Characteristics } & \multicolumn{1}{c|}{ The essence of characteristics } \\
\hline Viability & $\begin{array}{l}\text { Ability to maintain an acceptable level of efficiency of the enterprise } \\
\text { logistic activity in the face of disturbing factors }\end{array}$ \\
\hline Innovation & $\begin{array}{l}\text { Ability to develop and implement innovative technical-product and } \\
\text { information-management solutions that stimulate the development of } \\
\text { enterprise logistics system }\end{array}$ \\
\hline Integration & $\begin{array}{l}\text { Complex combination of external (participation in different supply chains } \\
\text { and formation of logistics infrastructure) and internal (single planning and } \\
\text { coordination of logistics processes at the enterprise, creation of corporate } \\
\text { logistical information system, etc.) integration }\end{array}$ \\
\hline Reliability & $\begin{array}{l}\text { Ability to implement logistic functions, while maintaining the values of } \\
\text { the established performance indicators within specified limits that meet } \\
\text { the specified conditions of activity }\end{array}$ \\
\hline Adaptability & $\begin{array}{l}\text { Ability to change the structure of the logistics system and choose options } \\
\text { for action according to new goals and under the influence of the } \\
\text { environment }\end{array}$ \\
\hline
\end{tabular}

Source: developed by the authors.

The deep integration of the logistics system in all spheres of production and economic activity of the enterprise causes its significant impact on the results of this activity. Characteristics of the contribution of 
the logistics system to the enterprise's activity are reflected in operating expenses, sales revenues, fixed and working capital, labor productivity, competitiveness and business efficiency.

Diagnostics of implementation of logistics processes involves their structural analysis with the construction of graphical diagrams and algorithms, analysis of all available information about processes, measurement of indicators of their efficiency and comparative analysis in order to assess their compliance with given requirements (standards, norms, plans), identify problem areas and search for solutions optimize workflows or use resources to increase productivity, minimize costs, and extend the production cycle of orders, increase the quality of logistics services, define the boundaries of responsibility between structural divisions and create additional customer value products or services.

The key to diagnostics is to identify and monitor changes in the results of the enterprise logistic activity, reflecting the ability of its logistics system, its individual functional subsystems and elements to qualitatively implement logistics processes and operations, accumulating their results, taking into account the influence of external and internal environmental factors.

The complex multilevel architecture of the logistics system of the enterprise causes the division of the results of logistic activities into general and partial. The first characterize the efficiency of logistics in the enterprise as a whole: the profitability of investments in the logistics system, forming long-term business relationships with business partners, the coordination of the units of the enterprise, saving resources, the level of quality of logistics customer service.

Groups of factors influencing the enterprise logistic activity

Table 2

\begin{tabular}{|c|c|}
\hline External factors & Internal factors \\
\hline $\begin{array}{l}\text { the market; } \\
\text { oducts in } \\
\text { y image; goc }\end{array}$ & \multirow{2}{*}{$\begin{array}{l}\text { Organizational - goals and objectives of } \\
\text { logistics management; organization of logistics } \\
\text { processes in the areas of supply, production and } \\
\text { distribution; corporate logistics culture; } \\
\text { competence of personnel of logistic units and } \\
\text { others. }\end{array}$} \\
\hline \multirow{2}{*}{$\begin{array}{l}\text { Geo-market - the location of the enterprise and its } \\
\text { counterparties, the level of development of } \\
\text { logistics infrastructure, etc. }\end{array}$} & \\
\hline & \multirow{2}{*}{$\begin{array}{l}\text { Financial - financial opportunities; organization } \\
\text { and characterization of financial flows related to } \\
\text { logistics activities; payment discipline; } \\
\text { inventory turnover, etc. }\end{array}$} \\
\hline 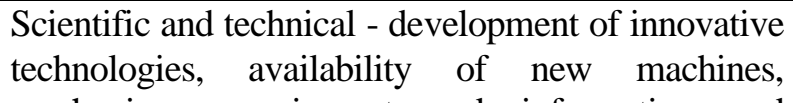 & \\
\hline & \multirow{2}{*}{$\begin{array}{l}\text { Production - types of production planning; } \\
\text { production capabilities of the equipment; } \\
\text { efficiency of working capital; reserve capacity; } \\
\text { quality management, etc. }\end{array}$} \\
\hline ant; & \\
\hline & \multirow{2}{*}{$\begin{array}{l}\text { Technical and technological - technical and } \\
\text { technological security of logistic } \\
\text { processes/operations; flexibility of technological } \\
\text { processes in logistics; the level of innovation of } \\
\text { hardware and technology (computerization, } \\
\text { automation, mechanization), etc. }\end{array}$} \\
\hline $\begin{array}{l}\text { ers - the nu } \\
\text { ers; descriptio }\end{array}$ & \\
\hline $\begin{array}{l}\text { of } \\
\text { tics }\end{array}$ & n; \\
\hline $\begin{array}{l}\text { umers - demand } f \\
\text { umer requirements } \\
\text { rral, psychological an } \\
\text { umers }\end{array}$ & $\begin{array}{l}\text { Information - communication channels at the } \\
\text { enterprise, availability of logistical information } \\
\text { systems, organization and characterization of } \\
\text { information flows related to logistics activities, } \\
\text { etc. }\end{array}$ \\
\hline
\end{tabular}

Source: developed by the authors. 
The second reflects the efficiency of the operation of individual logistics subsystems and elements, as well as the implementation of logistics flows, processes and operations: improving the performance of logistics subsystems, capacity utilization of logistics facilities and inventory turnover; improving the parameters of inbound, inbound and outbound logistics flows; reduction of logistical costs in individual areas and in general; timely execution of consumer orders; speed of service of vehicles, etc.

The results of the enterprise logistic activity are influenced by a large number of various external and internal factors, which require their constant monitoring and evaluation in order to adjust the goals and objectives, to better adapt to the changing conditions of activity. In the analysis of the environment, more attention should be paid to the factors of the so-called working environment, that is, to those market participants with whom the enterprise directly interacts in the course of its business activities, forming supply chains. There are the following groups of factors influencing the enterprise logistic activity (Table 2):

To analyze these factors, models of estimating the factor impact of the external and internal environment are formed, during which all factors influencing the enterprise logistic activity are determined, and the degree of their influence due to their quantification, and also the risks of changing their magnitude are evaluated.

The results of logistic activities are evaluated using a scorecard that contains key and local indicators with their subordination and differentiation, which provides a comprehensive evaluation of various aspects, types and characteristics of the enterprise logistics system, taking into account their mutual impact and achievement of goals (Fig. 3).

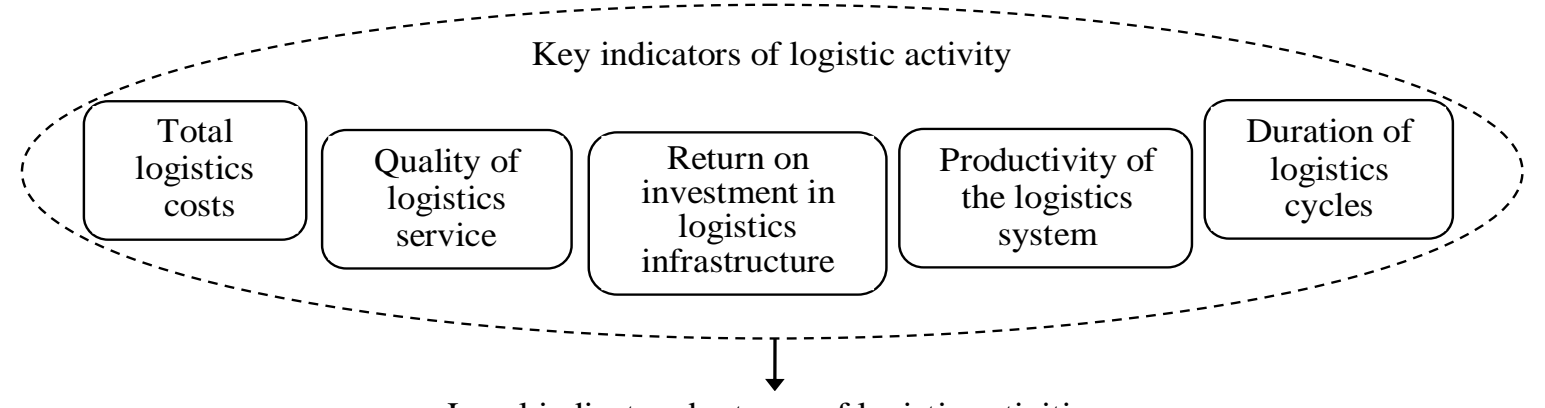

Local indicators by types of logistic activities

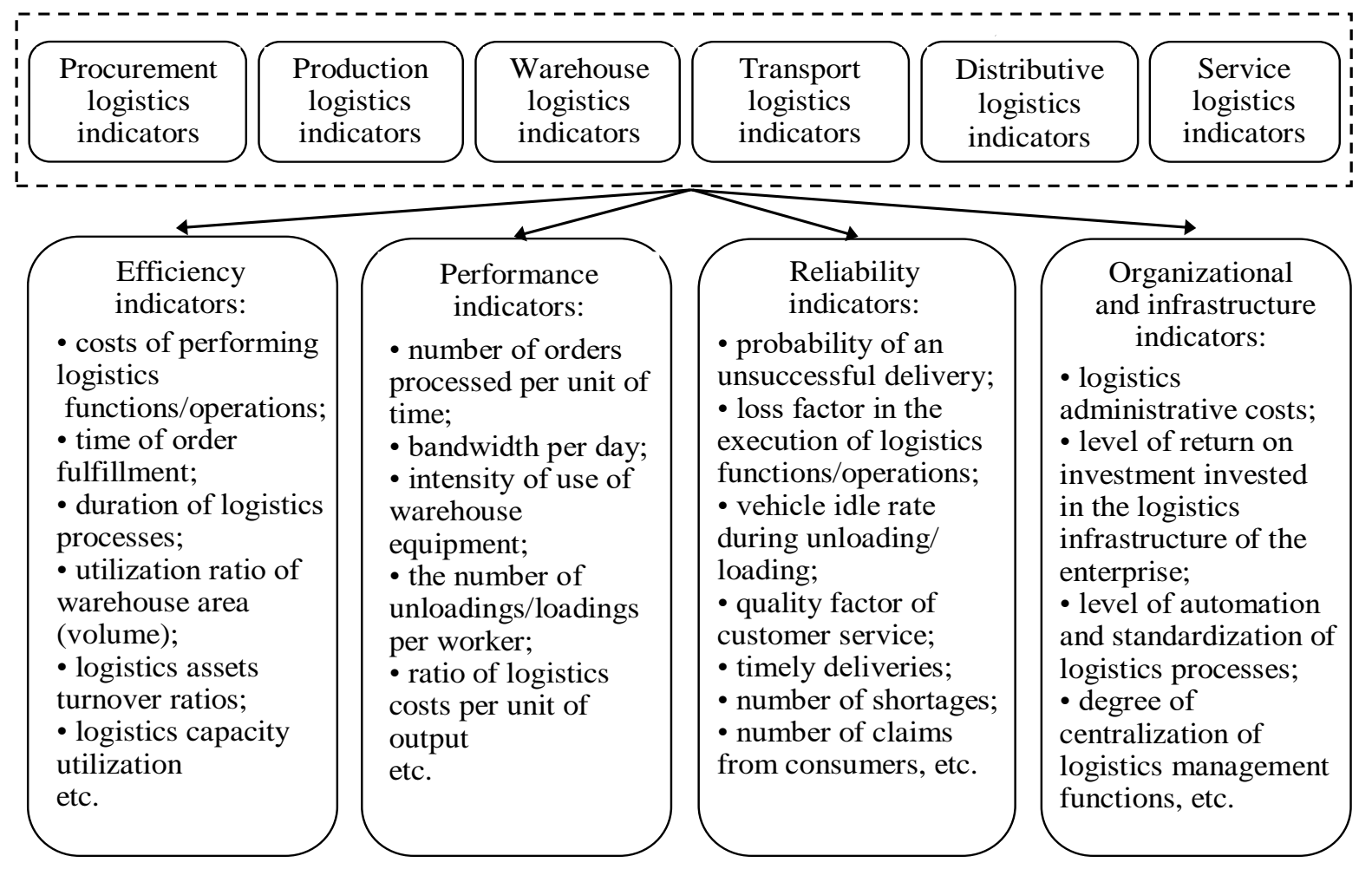

Fig. 3. The system of indicators of the enterprise logistic activity

Source: developed by the authors. 
Based on the tasks of diagnostics of the enterprise logistic activity different indicators are used: direct and indirect, absolute (single, total) and relative (specific, interrelated, indexes) in order to compare them with absolute standards, targets, past achievements and standards of competitors. When selecting indicators, in addition to the goals of diagnostics, their relevance, reliability, uniqueness, measurability, versatility and application character must also be taken into account.

In diagnosing the enterprise logistic activity a wide range of different groups of quantitative and qualitative methods that make up the scientific and methodological basis of economic diagnostics is used: economic and mathematical statistics, economic analysis, operations research and decision making, econometrics, economic cybernetics and mathematical programming, expert evaluations logic modeling. The most common in the diagnostic research of the enterprise logistic activity are the following methods:

- evaluation of natural indicators of logistic activity;

- estimation of total cost;

- ABC and XYZ analysis;

- group and multicriteria selection;

- modeling business processes using IDEF and ARIS technologies;

- heuristic analysis and synthesis;

- linear, nonlinear, dynamic and stochastic programming to solve optimization logistic problems;

- structural analysis and structural optimization.

It should be noted that the result of diagnostics is the development of recommendations for optimization of the enterprise logistic activity. It is from this stage that the effectiveness of managerial decisions on changes and directions of development of the logistics system of the enterprise that affect its market competitiveness and level of profitability depends. The development of recommendations takes into account identified "bottlenecks" during the diagnostics and hidden reserves of improvement of logistic activity, the degree of influence on it of factors of the external and internal environment, the results of forecasting the development of a problem situation and the ability of the enterprise to solve it.

The final stage of the diagnostic process is the monitoring of the effectiveness of the logistics decisions made, which allows to investigate their impact, evaluate the economic implications of their implementation and the degree of achievement of the management goal, compare the results of the logistic activity of the company before and after the implementation of measures.

In the changing conditions of the modern enterprise or the failure to achieve management objectives, the mechanism of diagnostics can be adjusted to the specific conditions of logistic activity by refining tasks, changing indicators and methods of diagnostics.

The opportunities given by the mechanism of logistic activity diagnostics, providing identification of weaknesses of logistics of the enterprise, timely response to problems in logistics activities, identifying reserves for the development of logistics system and finding ways to improve logistics processes, make it an effective tool in the process of managing production and economic activity.

Introduction of the mechanism of diagnostics of logistic activity will allow to move from estimation of separate quantitative indicators of characteristics of separate elements of the enterprise logistics system to a complex system of identification of the status and quality of implementation of logistics functions at the enterprise.

Conclusions. Diagnostics of logistics activities is a functional diagnostics that provides the identification, analysis, forecasting, modeling and elimination of problems in the field of enterprise logistics.

The implementation of the diagnostic process is carried out within the framework of a special mechanism, which, based on the principles of diagnostics, integrates into a single system methods, indicators, special measures and procedures for researching the logistics system and logistics processes of the enterprise, the influence of external and internal factors, the choice of which is determined by the goals and tasks of the diagnostics.

Characteristic features of the proposed mechanism of diagnostics of the enterprise logistic activity are its purposefulness, complexity, adaptability and multicriteria, which makes it possible to investigate a wide range of issues of organization and functioning of the logistics system of the enterprise, as well as to evaluate the effectiveness of logistics solutions. 
Application of the mechanism of logistic activity diagnostics equips the enterprise management with an effective tool of operational, tactical and strategic management, which not only prevents further deterioration of logistic activity efficiency and prevents possible logistical risks, but also identifies opportunities for development and optimization of logistic activity, correctly positions logistics in the overall structure of the enterprise, balance the logistics goals and strategy with the global strategy of the enterprise.

Prospects for further research are to improve the scientific and methodological basis of diagnostics on the basis of a combination of analytical and intellectual methods of business processes research, which will greatly expand the possibilities and efficiency of the mechanism of diagnostics of the enterprise logistic activity and may become the basis for its automation, which will lead to lower material costs for the diagnostics.

\section{References}

1. Діагностика стану підприємства: теорія і практика : монографія / за заг. ред. А.Е. Воронкової. Харків : ВД «ІНЖЕК», 2008. 448 с.

2. Кривов'язюк І.В. Економічна діагностика підприємства: теорія, методологія та практика застосування : монографія. Луцьк : Надстир'я , 2007. 260 с.

3. Marion A., Asquin A., Everaere C., Vinot D., Wissler M. Diagnostic de la performance de l'entreprise. Concepts et methods. Paris: Dunod, 2012. 320 p.

4. Мельник О.Г. Системи діагностики діяльності машинобудівних підприємств: полікритеріальна концепція та інструментарій : монографія. Львів: Видавництво Нац. ун-ту «Львівська політехніка», 2010. 344 с.

5. Kopytov R., Faingloz L., Cernavskis K. Using principle of complementarity when diagnosing complex logistic activities by applying alternative approach. Transport and Telecommunication. 2012. Vol. 13. No 4. P. 310321. DOI 10.2478/v10244-012-0027-3.

6. Посилкіна О.В., Хромих А.Г. Діагностика потенціалу внутрішньологістичної інтеграції процесів на вітчизняних фармацевтичних підприємствах. Фармаком. 2013. № 3. С. 90-98.

7. Чухрай Н. І., Гірна О. Б. Основні аспекти аудиту логістики в системі менеджменту. Вісник Наи. ун-ту «Львівська політехніка». Серія: Менеджмент та підприємництво в Україні: етапи становлення і проблеми розвитку. 2008. № 624. С. 110-116.

8. Коваленко Л.В., Филонов Н.Г. Позиционирование логистического анализа в управленческом анализе. Вестник ТГПУ. 2011. № 12 (114). С. 166-172.

9. Зернюк О.В., Ігнатенко В.О. Логістичний аналіз управління збутовою діяльністю промислового підприємства. Економіка і регіон. 2015. № 5 (54). С. 60-65.

10. Rafele C. Logistic service measurement: a reference framework. Journal of Manufacturing Technology Management. 2004. Vol. 15 No. 3, pp. 280-290. DOI https://doi.org/10.1108/17410380410523506.

11. Лукинский В.В., Шульженко Т.Г. Оценка эффективности логистической деятельности компании на основе ключевых показателей. Аудит и финансовый анализ. 2011. № 4. С. 160-167.

12. Саплина Т.И., Курлыкова А.В. Формирование системы сбалансированных показателей логистической деятельности предприятия. Вестник ОГУ. 2012. № 13 (149). С. 314-317.

13. Сумець О.М. Система оцінних показників результативності логістичної діяльності підприємства. Науковий вісник Херсонського державного університету. Серія: Економічні науки. 2014. Вип. 6. Ч. 3. С. 161164.

14. Скриньковський Р.М. Діагностика логістичної діяльності підприємства: теоретико-методичні аспекти. Молодий вчений. 2015. № 3(18). Ч. 2. С. 48-51.

15. Ткачова А.В. Оцінка ефективності логістичної діяльності промислового підприємства: інтегральний підхід. Прометей. 2011. № 2 (35). С. 156-161.

16. Чорнописька Н.В. Методичні підходи оцінювання логістичної діяльності підприємства. Вісник Наи. ун-ту «Львівська політехніка». Серія: Логістика. 2008. № 623. С. 265-271.

17. Кривякин К.С., Макаров Н.Н., Полухина А.А. Методика оценки эффективности логистической деятельности предприятия. Экономинфо. 2018. Т. 15. № 4. С. 54-59.

18. Веретенникова А.Б. Диагностика закупочной деятельности промышленного предприятия. БізнесІнформ. 2013. № 10. С. 93-95.

19. Телішевська О.Б. Оцінювання та діагностування витрат на логістично-постачальницьку діяльність підприємств за місцями їх виникнення та процесами логістично-постачальницького управління. Економіка: реалії часу. 2016. № 4 (26). С. 176-183. URL: http://economics.opu.ua/files/archive/ 2016/n4.html. 
20. Kolos I. Diagnostics in lean management system of industrial enterprise. Technology audit and production reserves. 2018. № 2/4 (40). P. 19-23.

21. Шпак С.А. Обоснование комплекса задач диагностики системы сбыта в планировании реструктуризации предприятий. Целевой подход. Бізнес-Інформ. 2013. № 4. С. 345-351.

\section{References}

1. Diahnostyka stanu pidpryiemstva: teoriia i praktyka (2008) [Diagnostics of the enterprise state: theory and practice]. Voronkova A.E. (Ed.). Kharkiv : VD «INZhEK» [in Ukrainian].

2. Kryvovyazyuk, I.V. (2007) Ekonomichna diagnostyka pidpryyemstva: teoriya, metodologiya ta praktyka zastosuvannya [Economic diagnostics of the enterprise: theory, methodology and practice of application]. Lutsk : Nadstyria [in Ukrainian].

3. Marion A., Asquin A., Everaere C., Vinot D., Wissler M. (2012) Diagnostic de la performance de l'entreprise. Concepts et methodes [Diagnostics of company performance. Concepts and Methods]. Paris: Dunod [in French].

4. Melnyk O.H. (2010) Systemy diahnostyky diialnosti mashynobudivnykh pidpryiemstv: polikryterialna kontseptsiia ta instrumentarii [Diagnostic systems for the activity of machine-building enterprises: a multicriteria concept and tools]. Lviv : Vydavnytstvo Nats. un-tu «Lvivska politekhnika» [in Ukrainian].

5. Kopytov R., Faingloz L., Cernavskis K. (2012) Using principle of complementarity when diagnosing complex logistic activities by applying alternative approach. Transport and Telecommunication, Vol. 13, No 4, 310-321. DOI 10.2478/v10244-012-0027-3.

6. Posylkina O.V., Khromykh A.H. (2013) Diahnostyka potentsialu vnutrishnolohistychnoi intehratsii protsesiv na vitchyznianykh farmatsevtychnykh pidpryiemstvakh [Diagnostics of the potential of intra-integration processes in domestic pharmaceutical enterprises]. Farmakom - Pharmacom, No 3, 90-98 [in Ukrainian].

7. Chukhrai N.I., Hirna O.B. (2008) Osnovni aspekty audytu lohistyky v systemi menedzhmentu [The main aspects of the audit of logistics in the management system]. Visnyk Nats. un-tu «Lvivska politekhnika». Seriia: Menedzhment ta pidpryiemnytstvo v Ukraini: etapy stanovlennia i problemy rozvytku - Herald Nat. University of Lviv Polytechnic. Series Management and Entrepreneurship in Ukraine: Formation Stages and Development Problems, No 624, 110-116 [in Ukrainian].

8. Kovalenko L.V., Fylonov N.H. (2011) Pozitsionirovanie logisticheskogo analiza v upravlencheskom analize [Logistic analysis positioning in management analysis]. Vestnik TGPU - Bulletin of TSPU, Vol. 114, No 12, 166-172 [in Russian].

9. Zerniuk O.V., Ihnatenko V.O. (2015) Lohistychnyi analiz upravlinnia zbutovoiu diialnistiu promyslovoho pidpryiemstva [Logistic analysis of sales management of an industrial enterprise]. Ekonomika i rehion - Economy and region, Vol. 54, No 5, 60-65 [in Ukrainian].

10. Rafele C. (2004) Logistic service measurement: a reference framework. Journal of Manufacturing Technology Management, Vol. 15, No. 3, 280-290. DOI https://doi.org/10.1108/17410380410523506.

11. Lukinskiy V.V., Shulzhenko T.G. (2011) Otsenka effektivnosti logisticheskoy deyatelnosti kompanii na osnove klyuchevyih pokazateley [Evaluation of the effectiveness of the company's logistics activities based on key indicators]. Audit i finansovyiy analiz - Audit and financial analysis, No. 4, 160-167 [in Russian].

12. Saplina T.I., Kurlyikova A.V. (2012) Formirovanie sistemyi sbalansirovannyih pokazateley logisticheskoy deyatelnosti predpriyatiya [Formation of a system of balanced indicators of the logistics activities of the enterprise]. Vestnik $O G U$ - Bulletin of OSU, Vol. 149, No. 13, 314-317 [in Russian].

13. Sumets O.M. (2014) Systema otsinnykh pokaznykiv rezultatyvnosti lohistychnoi diialnosti pidpryiemstva [The system of performance indicators of the logistics activity of the enterprise]. Naukovyi visnyk Khersonskoho derzhavnoho universytetu. Seriia: Ekonomichni nauky - Scientific Bulletin of Kherson State University. Series: Economics, No 6/3, 161-164 [in Ukrainian].

14. Skrynkovskyi R.M. (2015) Diahnostyka lohistychnoi diialnosti pidpryiemstva: teoretyko-metodychni aspekty [Diagnostics of the logistics activities of the enterprise: theoretical and methodological aspects]. Molodyi vchenyi - Young scientist, Vol. 18, No. 3/2, 48-51 [in Ukrainian].

15. Tkachova A.V. (2011) Otsinka efektyvnosti lohistychnoi diialnosti promyslovoho pidpryiemstva: intehralnyi pidkhid [Evaluation of the effectiveness of the logistics of an industrial enterprise: an integrated approach]. Prometei Prometheus, Vol. 35, No. 2, 156-161 [in Ukrainian].

16. Chornopyska N.V. (2008) Metodychni pidkhody otsiniuvannia lohistychnoi diialnosti pidpryiemstva [Methodological approaches to assess the logistics activities of the enterprise]. Visnyk Nats. un-tu «Lvivska politekhnika». Seriia: Lohistyka - Herald Nat. University of Lviv Polytechnic. Series: Logistics, No. 623, $265-271$ [in Ukrainian]. 
17. Krivyakin K.S., Makarov N.N., Poluhina A.A. (2018) Metodika otsenki effektivnosti logisticheskoy deyatelnosti predpriyatiya [Methodology for assessing the effectiveness of the logistics activities of the enterprise]. Ekonominfo - Econominfo, Vol. 15. No. 4, 54-59 [in Russian].

18. Veretennikova A.B. (2013) Diagnostika zakupochnoy deyatelnosti promyishlennogo predpriyatiya [Diagnostics of the procurement activities of an industrial enterprise]. Biznes-Inform - Business-Inform, No. 10, 93-95 [in Russian].

19. Telishevska O.B. (2016) Otsiniuvannia ta diahnostuvannia vytrat na lohistychno-postachalnytsku diialnist pidpryiemstv za mistsiamy yikh vynyknennia ta protsesamy lohistychno-postachalnytskoho upravlinnia [Assessing and diagnosing the costs of logistics activities of enterprises at their places of origin and processes of logistics management]. Ekonomika: realii chasu - Economics: the realities of time, Vol. 26, No. 4, 176-183. URL: http://economics.opu.ua/files/archive/ 2016/n4.html [in Ukrainian].

20. Kolos I. (2018) Diagnostics in lean management system of industrial enterprise. Technology audit and production reserves, Vol. 40, No. 2/4 (40), 19-23.

21. Shpak S.A. (2013) Obosnovanie kompleksa zadach diagnostiki sistemyi sbyita v planirovanii restrukturizatsii predpriyatiy. Tselevoy podhod [Justification of a set of tasks for diagnosing a sales system in planning enterprise restructuring. Target approach]. Biznes-Inform - Business-Inform, No. 4, 345-351 [in Russian].

Стаття надійшла до редакції 08.02.2020 р. 